\title{
Pengaruh Kuliah Kerja Nyata Mahasiswa Fakultas Ekonomi Universitas Samudra terhadap Pengembangan Kompetensi Sumber Daya Manusia
}

\author{
Syardiansah* \\ Program Studi Manajemen, Fakultas Ekonomi, Universitas Samudra, Indonesia \\ Diterima: Februari 2019; Disetujui: Maret 2019; Dipublish: April 2019 \\ *E-mail: syardiansah@unsam.ac.id
}

\begin{abstract}
Abstrak
Penelitian ini dilakukan untuk mengetahui pengaruh kuliah kerja nyata terhadap pengembangan kompetensi sumber daya manusia (mahasiswa) pada Fakultas Ekonomi Universitas Samudra yang sudah mengikuti kuliah kerja nyata pada tahun 2018. Jumlah responden pada penelitian ini sejumlah 150 orang mahasiswa yang berasal dari Program Studi Manajemen, Ekonomi Pembangunan dan Ekonomi Akuntansi tingkat IV yang sudah mengikuti kuliah kerja nyata pada tahun 2018. Dengan menggunakan rumus Slovin, maka jumlah mahasiswa sebagai sampel sejumlah 60 orang. Data pada penelitian ini diperoleh dari hasil penyebaran kuesioner kepada mahasiswa sebanyak 60 buah kuesioner yang semuanya dikembalikan tanpa cacat. Dari hasil analisis data diperoleh bahwa terdapat pengaruh positif dan signifikan dari KKN terhadap peningkatan kompetensi sumberdaya manusia yaitu kompetensi kepribadian dan kompetensi sosial. Dimana nilai koefisien determinasi $\left(\mathrm{R}^{2}\right)$ kompetensi kepribadian sebesar $21,2 \%$ sedangkan sisanya $78,8 \%$ dipengaruhi oleh variabel lain yang tidak diteliti dalam penelitian ini. Nilai koefisien determinasi $\left(R^{2}\right)$ kompetensi sosial sebesar $21,4 \%$ sedangkan sisanya 78,6\% dipengaruhi oleh variabel lain yang tidak diteliti dalam penelitian ini
\end{abstract}

Kata Kunci: Kuliah Kerja Nyata, Kompetensi, Sumber Daya Manusia

\begin{abstract}
This study was conducted to determine the effect of real work on the development of human resource competencies (students) at the Faculty of Economics at the University of Samudra who had attended real work classes in 2018. The number of respondents in this study was 150 students from the Management Study Program, Economics Level IV Development and Accounting Economics that has attended real work classes in 2018. Using the Slovin formula, there are 60 students as a sample. The data in this study were obtained from the results of distributing questionnaires to students as many as 60 questionnaires which were all returned without defects. From the results of data analysis, it was found that there were positive and significant influences on KKN on improving human resource competencies, namely personality competencies and social competencies. Where the coefficient of determination $\left(R^{2}\right)$ personality competence is $21.2 \%$ while the remaining $78.8 \%$ is influenced by other variables not examined in this study. The coefficient of determination $\left(R^{2}\right)$ of social competence is $21.4 \%$ while the remaining $78.6 \%$ is influenced by other variables not examined in this study

Keywords: Real Work Lecture, Competence, Human Resources

How to Cite: Syardiansah. (2019). Pengaruh Kuliah Kerja Nyata Mahasiswa Fakultas Ekonomi Universitas Samudra Terhadap Pengembangan Kompetensi Sumber Daya Manusia. Journal of Education, Humaniora and Social Sciences (JEHSS). 1 (3): 148-155.
\end{abstract}

\section{PENDAHULUAN}

Kuliah Kerja Nyata (KKN) adalah bagian dari sistem pendidikan tinggi yang menempatkan mahasiswa di luar kampus agar mahasiswa hidup ditengah-tengah masyarakat, bersama masyarakat untuk membantu dan mendampingi masyarakat memanfaatkan potensi sumber daya alam (SDA) lokal dan sumberdaya manusia (SDM) yang ada untuk mengatasi permasalahan masyarakat dalam kurun waktu tertentu. Kuliah Kerja Nyata (KKN) dapat dikatakan sebagai miniatur sebuah realitas sosial. Dalam pelaksanaannya, Kuliah Kerja Nyata (KKN) dapat melatih 
dan mengembangkan kemampuan praktis mahasiswa dalam menyelesaikan masalah-masalah sosial masyarakat. Dengan demikian, melalui kegiatan Kuliah Kerja Nyata (KKN), mahasiswa diharapkan dapat meningkatkan kepekaan sosial dan kedewasaan dalam mewujudkan tatanan kehidupan masyarakat yang lebih baik.

Selama berlangsungnya Kuliah Kerja Nyata (KKN) mahasiswa dihadapkan pada tantangan bagimana membuat dan melaksanakan program kerja baik individu maupun kolektif yang disesuaikan dengan kebutuhan masyarakat, evaluasi personal, interpersonal, ekstrapersonal, manajemen waktu dan finansial serta manajemen konflik internal maupun eksternal di lapangan. Untuk itu perlu pengelolaan yang lebih teratur dan terarah sehingga nilai strategis program KKN dapat didayagunakan dengan baik dan bermanfaat. Hasil pendidikan dibangku kuliah sekali lagi bukan hanya sekedar dengan mengukur angka-angka, tapi bagaimana ukuran dalam memberikan hati kepada masyarakat sehingga menjadi manusia-manusia unggul, bermantabat dan memiliki kompetensi.

Pelaksanaan Kuliah Kerja Nyata (KKN) merupakan bagian dari penyelenggaraan pendidikan dalam bentuk kegiatan pengamalan ilmu, teknologi, dan seni oleh mahasiswa kepada masyarakat. Kuliah Kerja Nyata (KKN) dilaksanakan secara melembaga dan terstruktur sebagai bagian dari pelaksanaan kurikulum pendidikan tinggi.

Dalam pelaksanaannya Kuliah Kerja Nyata (KKN) mempunyai ciri-ciri, yaitu: Pertama: interdisipliner, lintas sektoral dan komprehensif, maksudnya pola pikir yang ingin dikembangkan melalui kuliah kerja nyata bagi lembaga dilandasi oleh kenyataan, bahwa hampir setiap persoalan hidup dalam masyarakat mempunyai hubungan satu dengan yang lain (complicated), sehingga penyelesaian dengan pola pendekatan monodisiplin kurang efektif. Kuliah kerja nyata dimaksudkan untuk pengisi kekurangan tersebut dengan memberikan pengalaman cara berfikir interdisipliner, terpadu, dan komprehensif.

Kedua, Berdimensi luas, pragmatis, dan praktis, maksudnya kuliah kerja nyata bertolak dari fakta yang ada di masyarakat, serta timbulnya pelbagai persoalan di masyarakat perlu adanya pola pikir secara komprehensif dan pragmatis dengan pendekatan lintas ilmu, baik berdemensi eksakta maupun non eksakta, yang berteknologi maupun non teknologi. Pelbagai disiplin ini dan metode pendekatan sangat menunjang tingkat keberhasilan dalam pemecahan masalah serta pemberian solusi yang bermanfaat. Dengan pembekalan ilmu pengetahuan dan teknologi yang diperoleh dari bangku perkuliahan diharapkan dapat memberi sumbangan pemikiran, tenaga, dan lain sebagainya kepada masyarakat. Dalam kuliah kerja nyata mahasiswa didorong untuk mengadakan kegiatan di luar bidang studi dan mahasiswa dapat melakukan studi lintas disiplin ilmu dengan teman dari pelbagai fakultas lain maupun melakukan diskusi, bertukar pikiran serta pengalaman baik dengan teman maupun masyarakat tempat lokasi Kuliah Kerja Nyata (KKN), yang hasilnya dapat memberikan manfaat bagi semua pihak, yakni mahasiswa, pemerintah dan masyarakat.

Ketiga, keterpaduan antara pendidikan, penelitian dan pengabdian kepada masyarakat, yang termanifestasikan dalam Tri Dharma Perguruan Tinggi, maksudnya melalui Kuliah Kerja Nyata (KKN) mahasiswa mengenal persoalan masyarakat yang bersifat lintas sektoral serta belajar memecahkan masalah dengan pendekatan ilmu (interdisipliner). Mahasiswa perlu menelaah dan merumuskan masalah yang dihadapi masyarakat serta memberikan alternatif pemecahannya (penelitian), kemudian membantu memecahkan dan menanggulangi masalah tersebut. (unik-kediri.ac.id, 2018)

Universitas Samudra merupakan salah satu perguruan tinggi terkemuka di Aceh sudah banyak mengirimkan mahasiswanya ke daerah-daerah untuk melaksanakan Kuliah Kerja Nyata (KKN) sebagai wujud pelaksanaan tri dharma perguruan tinggi. Dalam pelaksanaannya Universitas Samudra selalu melakukan kerja sama dengan pihak pemerintah daerah, perusahaan, maupun pihak terkait lainnya untuk mendukung keberhasilan program Kuliah Kerja Nyata (KKN) yang dilakukan oleh mahasiswa. Pelaksanaan Kuliah Kerja Nyata (KKN) yang dilakukan oleh Universitas Samudra bertujuan untuk meningkatkan kemampuan mahasiswa baik bersifat 
personal maupun kelompok dalam membangun daerah yang terapkan program Kuliah Kerja Nyata (KKN) tersebut.

Dengan dilaksanakan program Kuliah Kerja Nyata (KKN) ini mahasiwa diharapkan mampu menerapkan ilmu yang telah didapat pada bangku kuliah dalam pelaksanaan program Kuliah Kerja Nyata (KKN), sehingga menjadikan mahasiswa yang siap pakai setelah lulus dari bangku kuliah. Dari sisi kompetensi mahasiswa didorong agar mampu memiliki kompetensi sosial dan kepribadian selama pelaksanaan Kuliah Kerja Nyata (KKN) tersebut. Dengan adanya kompetensi ini mahasiswa lebih siap dan lebih mudah dalam menyelesaikan program kegiatan Kuliah Kerja Nyata (KKN).

Kompetensi merupakan serangkaian perilaku yang menunjukkan kemampuan yang dimiliki oleh seseorang berdasarkan keterampilan serta pengetahuannya. Kompetensi juga memiliki sebuah kombinasi yang dapat dikatakan sempurna karena dalam kompetensi juga mengandalkan kemampuan dan juga keterampilan dalam mengerjakan sesuatu hal. Kompetensi ialah sesuatu yang selalu memiliki karakteristik tertentu berupa pengetahuan, keterampilan, serta tata cara perilaku yang menunjukkan kepribadian orang tersebut. Dalam konsep Inggris, diletakkan pemakaiannya pada tempat kerja. Sehinga dalam pekerjaan pun juga memiliki basis kompetensi yang baik pula. Kompetensi juga dipakai untuk pengukuran atau manajemen imbalan yang sesuai.

KKN (Kuliah Kerja Nyata) merupakan salah satu bentuk kegiatan pengabdian kepada masyarakat oleh Perguruan Tinggi yang dilakukan oleh mahasiswanya di bawah bimbingan dosen dan pimpinan pemerintah daerah. Adapun yang dimaksud pengabdian masyarakat ialah pengamalan ilmu pengetahuan, teknologi, dan seni yang dilakukan oleh Perguruan Tinggi secara ilmiah dan melembaga langsung kepada masyarakat untuk mensukseskan pembangunan dan pengembangan manusia menuju tercapainya manusia yang maju, adil, dan sejahtera berdasarkan Pancasila, serta meningkatkan pelaksanaan misi dan fungsi Perguruan Tinggi. Secara umum tujuan dari progam Kuliah Kerja Nyata (KKN) adalah menghasilkan lulusan Sarjana yang mampu menghayati dan menanggulangi masalah-masalah sosial yang kompleks. (Ahmad, 1997)

Pelaksanaan program kuliah kerja nyata untuk mengoptimalkan pencapaian maksud dan tujuan perguruan tinggi, yakni (unik-kediri.ac.id, 2018): 1) Menghasilkan sarjana yang menghayati permasalahan masyarakat dan mampu memberi solusi permasalahan secara pragmatis; 2) Membentuk kepribadian mahasiswa sebagai kader pembangunan dengan wawasan berfikir yang komprehensif.

Adapun manfaat kuliah kerja nyata, yakni (unik-kediri.ac.id, 2018): 1) Bagi Mahasiswa: a) Mendapatkan pemaknaan dan penghayatan mengenai manfaat ilmu,teknologi, dan seni bagi pelaksanaan pembangunan; b) Ketrampilan dalam merumuskan serta memecahkan persoalan yang bersifat "cross sectoral" secara pragmatis ilmiah dengan pendekatan interdisipliner; c) Tumbuhnya rasa kepedulian sosial dan rasa kesejawatan. 2) Bagi Masyarakat dan Pemerintah: a) Pemberian bantuan pemikiran dan tenaga dalam pemecahan masalah pembangunan daerah setempat; b) Pola pikir dalam merencanakan, merumuskan, melaksanakan berbagai program pembangunan, khususnya dipedesaan yang kemungkinan masih dianggap baru bagi masyarakat setempat; c) Tumbuhnya dorongan potensi dan inovasi di kalangan anggota masyarakat setempat dalam upaya memenuhi kebutuhan lewat pemanfaatan ilmu dan teknologi. 3) Bagi Perguruan Tinggi: a) Melalui mahasiswa/ dosen pembimbing, diperoleh umpan-balik sebagai pengayaan materi kuliah, penyempurnaan kurikulum, dan sumber inspirasi bagi suatu rancangan bentuk pengabdian kepada masyarakat yang lain atau penelitian; b) Diperolehnya bahan masukan bagi peningkatan atau perluasan kerjasama dengan pemerintahan setempat, termasuk dengan instansi vertikal yang terkait.

Dalam pelaksanaan Kuliah Kerja Nyata (KKN) mahasiswa harus mampu berpartisipasi dan memberdayakan masyarakat. Partisipasi dapat didefinisikan sebagai keterlibatan mental dan emosional seseorang dalam situasi kelompok yang mendorong dia untuk berkontribusi tujuan kelompok dan berbagi tanggung jawab di dalamnya (Keith, 2003).

Sedangkan pemberdayaan masyarakat adalah menjadikan mereka sebagai partner dalam menjalankan sebuah program (Billet, 2007). Ada beberapa hal penting yang perlu dipegang agar 
sukses dalam pemberdayaan masyarakat, yaitu: 1) membangun dan memelihara maksud dan tujuan bersama; 2) membangun dan memelihara hubungan dengan partner; 3) membangun dan memelihara kapasitas program bersama; 4) membangun dan memelihara kepemimpinan dan: 5) membangun dan memelihara kepercayaan dan saling percaya.

Kompetensi secara harfiah dapat diartikan sebagai kemampuan (Siti, 2011). Tentang pengertian kompetensi, terdapat beberapa rumusan dan definisi yang dikemukakan oleh para ahli. Menurut Syaiful Sagala (2008), kompetensi merupakan peleburan dari pengetahuan (daya pikir), sikap (daya kalbu), dan ketrampilan (daya fisik) yang diwujudkan dalam bentuk perbuatan. Sedangkan menurut Usman Kunandar (2007), kompetensi adalah suatu hal yang menggambarkan kualifikasi dan kemampuan seorang, baik yang kualitatif maupun kuantitatif. Kompetensi juga berarti sebagai pengetahuan, ketrampilan dan nilai-nilai dasar yang direfleksikan dalam kebiasaan berpikir dan bertindak. Jadi, dengan kata lain kompetensi merupakan perpaduan dari penguasaan pengetahuan, ketrampilan, nilai, dan sikap yang direfleksikan dalam kebiasaan berpikir dan bertindak dalam melaksanakan tugas atau pekerjaannya.

Kompetensi dapat didefinisikan sebagai spesifikasi dari pengetahuan, ketrampilan, dan sikap yang dimiliki seseorang serta penerapannya dalam pekerjaan, sesuai dengan standar kinerja yang dibutuhkan oleh masyarakat dan dunia kerja (Danim, 2011). Definisi tersebut sesuai dengan penjelasan Weinert mengenai kompetensi (Eveline, 2017): "Competence as the combination of an individual's knowledge, ability, and willingness to cope successfully with situational demands. Competence is therefore a multimensional construct that cognitive and noncognitive aspect and this must be viewed from a holistic perspective. (Artinya kompetensi adalah kesatuan antara pengetahuan, kemampuan, dan kemauan individu untuk mencapai kesuksesan dengan tuntutan situasi tertentu, oleh karena itu, kompetensi merupakan konstruksi multidimensional baik dari aspek pengetahuan maupun selain pengetahuan, dan ini harus dilihat secara menyeluruh.) Menurut Kamus Umum Bahasa Indonesia karangan WJS Purwadarminto (1999), pengertian kompetensi adalah kekuasaan untuk menentukan atau memutuskan suatu hal. Pengertian dasar kompetensi adalah kemampuan atau kecakapan.

Dalam kamus Besar Bahasa Indonesia (2007), kompetensi sosial mempunyai arti segala sesuatu yang berkenaan dengan masyarakat. Dengan kata lain, sosial berhubungan dengan interaksi timbal balik antara individu satu dengan individu lainnya, individu dengan kelompok, maupun kelompok dengan kelompok. Sedangkan yang dimaksud dengan kompetensi kepribadian adalah kemampuan kepribadian yang mantap, berakhlak mulia, arif, dan berwibawa serta menjadi teladan dalam kehidupan sehari-hari, kata kepribadian digunakan untuk menggambarkan: (1) identitas diri, jati diri seseorang dan, (2) kesan umum seseorang tentang diri anda atau orang lain. Lebih lengkapnya, Allport (2007) memberikan definisi, "personality is the dynamic organization within the individual of those psychophysical system, that determines his unique adjustment to his environment. (Artinya kepribadian adalah suatu organisasi yang dinamis dari system psikofisis dalam individu yang menentukan keunikan penyesuaian diri terhadap lingkungan).

Spencer dan Spencer dalam Uno (2008), kompetensi merupakan karakteristik yang menonjol bagi seseorang dan menjadi cara-cara berperilaku dan berfikir dalam segala situasi, dan berlangsung dalam periode waktu yang lama. Dari pendapat tersebut dapat dipahami bahwa kompetensi menunjuk pada kinerja seseorang dalam suatu pekerjaan yang bisa dilihat dari pikiran, sikap, dan perilaku. Lebih lanjut Spencer dan Spencer dalam Hamzah B. Uno (2008), membagi lima karakteristik kompetensi yaitu sebagai berikut. 1) Motif, yaitu sesuatu yang orang pikirkan dan inginkan yang menyebabkan sesuatu. 2) Sifat, yaitu karakteritik fisik tanggapan konsisten terhadap situasi. 3) Konsep diri, yaitu sikap, nilai, dan image dari sesorang. 4) Pengetahuan, yaitu informasi yang dimiliki seseorang dalam bidang tertentu. 5) Ketrampilan, yaitu kemampuan untuk melakukan tugas-tugas yang berkaitan dengan fisik dan mental. 
DOI: https://doi.org/10.34007/jehss.v113.26

Sonny Sumarsono (2003) mengartikan bahwa sumber daya manusia mempuyai beberapa pengertian yaitu sumber daya manusia adalah usaha kerja yang bermanfaat bagi keberlangsungan produksi. Sedangkan makna yang kedua, sumber daya manusia merupakan kelompok manusia yang terdiri dari manusia yang memiliki kemampuan untuk memberikan jasa. Dalam hal lain SDM mencerminkan kualitas usaha yang diberikan oleh seseorang dalam waktu tertentu untuk menghasilkan barang dan jasa. Pengertian kedua, Sumber Daya Manusia (SDM) menyangkut manusia yang mampu bekerja untuk memberikan jasa atau usaha kerja tersebut. Mampu bekerja berarti mampu melakukan kegiatan yang mempunyai kegiatan ekonomis, yaitu bahwa kegiatan tersebut menghasilkan barang atau jasa untuk memenuhi kebutuhan atau masyarakat.

Menurut Mathis dan Jackson (2006), sumber daya manusia merupakan suatu rancangan berbagai sistem formal dalam perusahaan maupun organisasi yang berfungsi untuk menjaga agar penggunaan bakat dan minat manusia dapat digunakan untuk mencapai tujuan organisasi atau perusahaan tersebut secara efektif dan efisien. Sedangkan menurut Hasibuan (2003) sumber daya manusia adalah manusia yang mempunyai kemampuan terpadu yang dicirikan dengan pola pikir dan daya fisik yang baik. Perilaku dan watak sumber daya manusia berasal dari lingkungannya sedangkan prestasi dan motivasi kerja berasal dari keinginan dirinya sendiri. SDM terdiri dari daya fikir dan daya fisik setiap manusia. Tegasnya kemampuan setiap manusia ditentukan oleh daya fikir dan daya fisiknya. SDM atau manusia menjadi unsur utama dalam setiap aktivitas yang dilakukan. Peralatan yang handal atau canggih tanpa peran aktif SDM, tidak berarti apa-apa. Daya pikir adalah kecerdasan yang dibawa sejak lahir (modal dasar) sedangkan kecakapan diperoleh dari usaha (belajar dan pelatihan). Kecerdasan tolok ukurnya Intelegence Quotient (IQ) dan Emotion Quality (EQ).

Pengelolaan sumber daya manusia identik dengan manajemen sumber daya manusia. Noe, Hollenbeck, Gerhart dan Wright (2008) mengemukakan manajemen sumber daya manusia merupakan kebijakan, praktek dan sistem yang mempengaruhi perilaku, tindakan dan kinerja karyawan. Praktek manajemen sumber daya manusia termasuk menganalisa dan mendesain pekerjaan, menentukan kebutuhan sumber daya manusia, merekrut calon karyawan potensial, memilih karyawan (seleksi), mengajari karyawan akan tugas-tugas mereka (pelatihan), menyiapkan kemampuan mereka untuk masa depan (pengembangan), memberikan kompensasi dan melakukan penilaian kinerja terhadap karyawan. Sedangkan menurut Mangkunegara (2011), manajemen sumber daya manusia merupakan suatu perencanaan, pengorganisasian, pengkoordinasian, pelaksanaan dan pengawasan terhadap pengadaan, pengembangan, pemberian balas jasa, pengintegrasian, pemeliharaan, dan pemisahan tenaga kerja dalam rangka mencapai tujuan organisasi.

Dalam fungsi Sumber Daya Manusia (SDM), terdapat beberapa praktek aktivitas organisasi dalam mengelola tenaga kerjanya yaitu dimulai dari pengadaan tenaga kerja, pelatihan dan pengembangan, pemberian kompensasi, pemeliharaan hubungan dan pemisahan tenaga kerja. Praktek-praktek pengelolaan semacam ini mempengaruhi efektivitas dan efisiensi sumber daya manusia organisasi (Sintong, 2014). Pengadaan tenaga kerja antara lain terdiri atas analisis pekerjaan, penarikan (rekrutmen) dan seleksi calon karyawan. Analisis pekerjaan merupakan suatu proses penentuan yang sistematis untuk menentukan uraian pekerjaan (tugas-tugas) dan spesifikasi pekerjaan (keterampilan dan pengetahuan yang dibutuhkan untuk melakukan pekerjaan dalam sebuah organisasi). (Panggabean, 2004). Dan fungsi sumber daya manusia merupakan fungsi organisasi yang bertugas untuk membuat sistem dan kebijakan yang mempengaruhi perilaku, sikap dan kinerja karyawan. Praktek-praktek yang terdapat dalam fungsi sumber daya manusia adalah perekrutan, seleksi, pelatihan, pengembangan, kompensasi dan pemberhentian tenaga kerja. (Noe, Hollenbeck, Gerhart \& Wright, 2008)

Berdasarkan uraian latar belakang dan dikaitkan dengan telaah teoritis dan empiris terdahulu, hipotesisnya yaitu: terdapat pengaruh kuliah kerja nyata terhadap peningkatan kompetensi sumber daya manusia pada mahasiswa KKN Tahun 2018 Fakultas Ekonomi Universitas Samudra. 


\section{METODE PENELITIAN}

Dalam penelitian ini angket digunakan untuk memperoleh data dari responden tentang kunjungan studi, kuliah kerja nyata dan peningkatan kompetensi. Penelitian ini menggunakan metode survey dengan angket berupa kuesioner yang dibagikan kepada mahasiswa KKN tahun 2018 Fakultas Ekonomi Universitas Samudra yang menjadi respondennya. Kuesioner menggunakan skala Likert. Sugiyono (2011) menjelaskan, skala Likert digunakan untuk mengukur sikap, pendapat, dan persepsi seseorang atau sekelompok orang tentang fenomena sosial. Sugiyono (2011) menyatakan "instrumen penelitian adalah suatu alat yang digunakan mengukur fenomena alam maupun sosial yang diamati". Instrumen penelitian yang digunakan dalam penelitian ini adalah angket atau kuesioner. Instrumen dalam penelitian ini menggunakan menggunakan skala Likert dengan opsi jawaban sangat setuju, setuju, netral, tidak setuju, dan sangat tidak setuju.

Pengambilan sampel yang digunakan dalam penelitian ini adalah teknik probability sampling. Jenis probability sampling yang digunakan yaitu proportional random sampling, sehingga masing-masing kelas diambil sampel secara proporsional. Adapun ukuran sampel dari populasi penelitian ini ditentukan dengan menggunakan rumus Slovin.

Populasi dalam penelitian ini berjumlah 150 orang mahasiswa KKN tahun 2018 yang terdiri dari program studi Manajemen sebanyak 30 orang, Ekonomi Pembangunan sebanyak 60 orang dan Akuntansi sebanyak 60 orang. Pengambilan sampel dilakukan secara acak kepada mahasiswa dengan menggunakan rumus Slovin:

$$
n=\frac{N}{1+N \cdot e^{2}}
$$

$$
\begin{aligned}
& \text { Dimana: } \\
& \mathrm{n}=\text { ukuran sampel } \\
& \mathrm{N}=\text { ukuran populasi } \\
& \mathrm{e}=\text { persen kelonggaran ketidaktelitian karena kesalahan pengambilan sampel } \\
& \text { maka jumlah sampel pada penilitian ini adalah: } \\
& n=\frac{150}{1+150 \cdot(10 \%)^{2}} \\
& =60
\end{aligned}
$$

Jadi, sampel penelitian yang digunakan untuk mewakili populasi penelitian berjumlah 60 orang.

Teknik analisis data dalam penelitian ini menggunakan program SPSS 20.0 for Windows. Penelitian ini menggunakan analisis deskriptif dan uji asumsi klasik. Sugiyono (2010) mendefinisikan "statistik deskriptif adalah statistik yang digunakan untuk menganalisa data dengan cara mendeskripsikan atau menggambarkan data yang telah terkumpul sebagaimana adanya tanpa bermaksud membuat kesimpulan yang berlaku untuk umum atau generalisasi".

Penelitian ini menggunakan statistik deskriptif dengan menggunakan table distribusi frekuensi untuk mendeskripsikan tentang pengaruh KKN terhadap pengembangan kompetensi sumber daya manusia mahasiswa. Uji asumsi klasik yang digunakan untuk mengetahui apakah model regresi layak digunakan dalam penelitian. Berikut ini adalah beberapa model uji asumsi klasik yang digunakan dalam penelitian ini yaitu: uji normalitas dan uji heteroskedastisitas. Uji normalitas dapat dideteksi dengan melihat penyebaran data di sekitar garis diagonal serta menyebar mengikuti garis diagonal, maka model regresi tersebut memenuhi asumsi normalitas, atau sebaliknya.

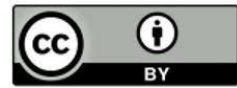


Model regresi yang baik adalah jika tidak terjadi heteroskedastisitas. Santoso (2012) juga menjelaskan "Jika varians ada residual dari satu pengamatan ke pengamatan yang lain tetap, maka disebut Homokedastisitas". Ada tidaknya gejala heteroskedastisitas dapat dilihat pada grafik scatterplot di sekitar nilai X dan Y.

Priyatno (2012) menjelaskan "Jika ada pola tertentu, seperti titik-titik yang ada membentuk suatu pola tertentu yang teratur (bergelombang, melebar kemudian menyempit), maka terjadi heteroskedastisitas"

\section{HASIL DAN PEMBAHASAN}

Untuk memperoleh data dalam penelitian ini dilakukan penyebaran kuesioner yang terhadap 60 orang responden yang seluruhnya adalah mahasiswa tingkat IV Fakultas Ekonomi Universitas Samudra yang sudah mengikuti KKN pada tahun 2018.

Persamaan regresi linier sederhana $Y=1,852+0,476 \mathrm{X}$. Berdasarkan persamaan ini dapat diterjemahkan bahwa: 1) Konstanta sebesar 1,852 menunjukkan nilai Kompetensi Kepribadian apabila Kuliah Kerja Nyata bernilai nol (tetap); 2) Variabel KKN menunjukkan pengaruh yang positif terhadap Kompetensi Kepribadian sebesar 0,476. Jadi apabila KKN naik satu satuan maka Kompetensi Kepribadian akan meningkat sebesar 0,476 satuan dengan asumsi variable lain tetap.

Model regresi ini baik karena tidak terjadi heteroskedastisitas. Yaitu tidak ada pola tertentu, seperti titik-titik yang ada membentuk suatu pola tertentu yang teratur (bergelombang, melebar kemudian menyempit). Maka diperoleh persamaan regresi linier sederhana $Y=1,763+$ 0,539X. Berdasarkan persamaan ini dapat diterjemahkan bahwa: 1) Konstanta sebesar 1,763 menunjukkan nilai Kompetensi Sosial apabila Kuliah Kerja Nyata bernilai nol (tetap). 2) Variabel KKN menunjukkan pengaruh yang positif terhadap Kompetensi Sosial sebesar 0,539. Jadi apabila KKN naik satu satuan maka Kompetensi Kepribadian akan meningkat sebesar 0,539 satuan dengan asumsi variable lain tetap.

Model regresi ini baik karena tidak terjadi heteroskedastisitas. Yaitu tidak ada pola tertentu, seperti titik-titik yang ada membentuk suatu pola tertentu yang teratur (bergelombang, melebar kemudian menyempit). Untuk mengetahui pengaruh dari variabel bebas terhadap variabel terikat digunakan teknik analisis data dengan uji t, sebagai berikut: 1) Berdasarkan tabel 1 diperoleh nilai uji $t_{\text {sig }}$ variabel bebas (kuliah kerja nyata) menunjukkan nilai signifikansi sebesar $0,000<0,05$ maka kuliah kerja nyata berpengaruh signifikan terhadap peningkatan kompetensi kepribadian; 2) Berdasarkan tabel 2 diperoleh nilai uji $t_{\text {sig }}$ variabel bebas (kuliah kerja nyata) menunjukkan nilai signifikansi sebesar $0,000<0,05$ maka kuliah kerja nyata berpengaruh signifikan terhadap peningkatan kompetensi sosial.

Nilai R Square sebesar 0,212 . Hal ini berarti variabel kuliah kerja nyata mempengaruhi kompetensi kepribadian pada mahasiswa KKN tahun 2018 Fakultas Ekonomi sebesar 21,2\% sedangkan sisanya 78,8\% dipengaruhi oleh variabel lain yang tidak diteliti dalam penelitian ini.

Nilai R Square sebesar 0,214 . Hal ini berarti variabel kuliah kerja nyata mempengaruhi kompetensi sosial pada mahasiswa KKN tahun 2018 Fakultas Ekonomi sebesar 21,4\% sedangkan sisanya $78,6 \%$ dipengaruhi oleh variabel lain yang tidak diteliti dalam penelitian ini.

\section{SIMPULAN}

Dengan berdasarkan hasil perhitungan dan pengolahan data dalam penelitian ini telah dianalisis untuk mendapatkan adanya atau tidak pengaruh KKN terhadap peningkatan kompetensi sumberdaya manusia mahasiswa yang mengikuti KKN tahun 2018 Fakultas Ekonomi Universitas Samudra, maka peneliti dapat mengambil kesimpulan bahwa terdapat pengaruh positif dan signifikan dari KKN terhadap peningkatan kompetensi sumberdaya manusia yaitu kompetensi kepribadian dan kompetensi sosial. Dimana nilai koefisien determinasi $\left(\mathrm{R}^{2}\right)$ kompetensi kepribadian sebesar 21,2\% sedangkan sisanya 78,8\% dipengaruhi oleh variabel lain yang $\mathrm{t}$ 
Syardiansah. Pengaruh Kuliah Kerja Nyata Mahasiswa Fakultas Ekonomi Universitas Samudra Terhadap

idak diteliti dalam penelitian ini. Nilai koefisien determinasi $\left(\mathrm{R}^{2}\right)$ kompetensi sosial sebesar $21,4 \%$ sedangkan sisanya $78,6 \%$ dipengaruhi oleh variabel lain yang tidak diteliti dalam penelitian ini

\section{DAFTAR PUSTAKA}

Ahmad, F. dkk. (1997). Pedoman Pelaksanaan Kuliah Kerja Nyata (KKN). Jakarta: Rineka Cipta.

Billet, S. et. all. (2007). Collaborative Working and Contested Practices: forming. Developing and Sustaining Social Partnerships in Education. Journal of Education Policy. Vol 22. No. 6.

Danim, S. (2011). Pengembangan Profesi Guru. Jakarta: Kencana

Hasibuan, M.S.P. (2003). Organisasi dan Motivasi Dasar Peningkatan Produktivitas. Jakarta: Bumi Aksara.

http://unik-kediri.ac.id/?page id=278, diakses tanggal 1 Juli 2018

Keith, D. (2003). Human Relation At Work: The Dynamics of Organizational Behavior. Japan: Mcgraw-Hill.

Kunandar, U. (2007). Guru Professional: Implementasi Kurikulum Tingkat Satuan Pendidikan dan Sukses

Dalam Sertifikasi Guru. Jakarta: Raja Grafindo Persada

Mangkunegara, A.A. (2011). Manajemen Sumber Daya Manusia Perusahaan. Bandung: Rosda

Mathis, R.L., \& Jackson, J.H. (2006). Human Resource Management. Jakarta: Salemba Empat.

Noe, H. Gerhart dan Wright. (2008). Human Resource Management: Gaining a Competitive Advantage. New York: Mcgraw-Hill

Nurihsan, A.J. dan Yusuf, S (2007). Teori kepribadian. Bandung: PT Remaja Rosdakarya

Panggabean, M.S. (2004). Manajemen Sumber Daya Manusia. Bogor: Ghalia Indonesia

Priyatno, D. (2012). Cara Kilat Belajar Analisis Data dengan SPSS 20. Yogyakarta: Andi

Rimang, S.W. (2011). Meraih Predikat Guru dan Dosen Paripurna". Bandung: Alfabeta

Sagala, S. (2008). Kemampuan Profesional Guru dan Tenaga Kependidikan. Bandung: Alfabeta

Santoso, S. (2012). Aplikasi SPSS pada Statistik Parametik. Jakarta: PT. Elex Media Komputindo

Sintong, M. (2014). Kebijakan Berwawasan Kependudukan dan Peningkatan Kualitas Sumber Daya Manusia, Jurnal Pendidikan Ilmu-Ilmu Sosial, 6 (2) (2014): 107-117.

Sugiyono. (2010). Metode Penelitian Bisnis. Bandung: Alfabeta

Sugiyono. (2011). Metode Penelitian Kuantitatif, Kualitatif, dan R\&D. Bandung: Alfabeta

Sugiyono. (2013). Metode Penelitian Pendidikan (Pendekatan Kuantitatif, Kualitatif, dan R\&D). Bandung: Penerbit Alfabeta,

Sumarsono, S. (2003). Ekonomi Manajemen Sumber Daya Manusia dan Ketenagakerjaan. Yogyakarta: Graha Ilmu.

Tim Penyusun Kamus Pusat Bahasa. 2007. Kamus Besar Bahasa Indonesia, Jakarta: Balai Pustaka

Uno, H.B. (2008), Perencanaan Pembelajaran, PT Bumi Aksara, Jakarta

Wuttke, E. and Seifried, J. (2017). Professional Error Competence Of Preservice Teachers: Evaluation and Support. Germany: Springer International Publishing.

Zimmerer, T.W., dkk. (2008). Kewirausahaan Dan Manajemen Usaha Kecil. Jakarta: Salemba Empat.

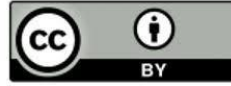

